Piotr Banasik

ORCID: 0000-0002-3604-4019

\title{
ICONOGRAPHIC AND CARTOGRAPHIC BIOGRAPHY OF THE ESTERKA MOUND IN LOBZÓW
}

\author{
AGH University of Science and Technology, Kraków, Poland \\ pbanasik@agh.edu.pl
}

Keywords: Esterka Mound, archival maps and archival photographs

\begin{abstract}
The paper refers to one of the mounds in Kraków - the Esterka Mound. This mound was probably the element of a garden established at the palace in the former village of Łobzów (nowadays a part of the city quarter Kraków-Krowodrza). The available so far information on the mound is scattered all over numerous publications, and sometimes contains errors. This also refers to iconographic materials. In this paper the remaining iconographic and cartographic materials referring to this object were collected and put together in a systematic way. The paper also contains bibliographic documentation of the existing graphic materials showing the mound (panoramas, terrain sketches, maps, photographs). The information available in this article can be used in the plans of revitalizing the Esterka Mound and former royal mansion in Łobzów.
\end{abstract}

\section{IKONOGRAFICZNA I KARTOGRAFICZNA BIOGRAFIA KOPCA ESTERKI W LOBZOWIE}

Słowa kluczowe: kopiec Esterki, archiwalne mapy i rysunki, archiwalne fotografie

\begin{abstract}
Abstrakt
Praca dotyczy jednego z kopców krakowskich - kopca Esterki w Krakowie. Kopiec ten najprawdopodobniej był elementem ogrodu założonego przy pałacu w dawnej wsi Łobzów (obecnie w dzielnicy Kraków-Krowodrza). Dotychczasowe informacje o kopcu są rozproszone w wielu publikacjach, a niekiedy zawierają błędy. Dotyczy to również materiałów ikonograficznych. W pracy zebrano i usystematyzowano dostępne materiały ikonograficzne i kartograficzne, jakie pozostały po tym obiekcie. Sporządzono dokumentację bibliograficzną istniejących materiałów graficznych pokazujących kopiec (panoramy, plany, mapy, fotografie). Informacje znajdujące się w artykule mogą zostać wykorzystane w planach rewitalizacji kopca Esterki i dawnej rezydencji królewskiej w Łobzowie.
\end{abstract}

\section{INTRODUCTION}

The history of constructing mounds goes back to prehistoric times. Their main function was burial (barrows). Such objects can be found in Europe, Asia and the Americas. Earth construction of a conic mound was supported by wooden and stone enforcement. In the cen- tral part of a barrow there was a funerary chamber [1]. In the past, mounds had also religious and ceremonial functions (places of worship) observation function (e.g., astronomic observations) or defence functions when fortresses were built on the tops of them [2]. It was documented that mounds were used to determine important dates in the oldest astronomic calendars [3], [4], [5]. 
On the other hand, mounds constructed over the recent centuries were meant to commemorate important people or events (memorial and patriotic mounds). Mounds were also treated as decorative elements (garden mounds and scenery-view mounds) [6].

The highest density of mounds in the area of Poland occurs in south-east part of the country [7], [8]. The best known are two modern patriotic mounds in Kraków: the Kosciuszko Mound of 1823 and Piłsudski Mound of 1937 and prehistoric mounds: the Krakus Mound in Podgórze and the Wanda Mound in Mogiła. Less known is the John Paul II Memorial Mound in Zakrzówek [9], and the barrow mound in the Protestant cemetery in Łuczanowice [10], as well as mounds in cone-like hill forts, e.g., in Boczów (the Bochnia District) and in Malec (the Oświęcim District). Among the completely forgotten mounds are a small mound on the Wawel hill [11] and equally mysterious and now non-existing Esterka Mound in Łobzów. The appearance and situation of the latter was, however, documented in old drawings, maps and photographs. This paper contains the characteristics of documents, showing the shape of the Esterka Mound and its situation. The goal of the paper is systematizing the existing iconographic and cartographic materials, where this mound was presented. This is the development and supplementation of the descriptive information contained, inter alia, in publication [12]. The information presented below can make an auxiliary material in the plans to revitalize this area of Kraków. Such attempts have been made for a long time [13], [14], [15]. Among other issues, the restoration of the Esterka Mound is considered.

\section{ICONOGRAPHY OF THE ESTERKA MOUND}

The Esterka Mound was in the northern part of a former garden at the palace in Łobzów. The palace was built at the turn of $16^{\text {th }}$ and $17^{\text {th }}$ century, in the place of the old royal mansion and the project included a garden of regular shapes [16], [17]. The oldest drawings come from this period. They show the palace and garden with the Esterka Mound. These are panoramas of Kraków, usually drawn based on hand-made sketches or even oral descriptions of people visiting Kraków [18]. The Esterka Mound was placed in the panorama of Kraków: „Cracovia Metropolis Regni Poloniae” pubished in „Civitates Orbis Terrarum vol. 6", issued in 1617 [19]. The panorama presents Kraków seen from the north-west. The presented appearance comes from 1603-1605 [18].

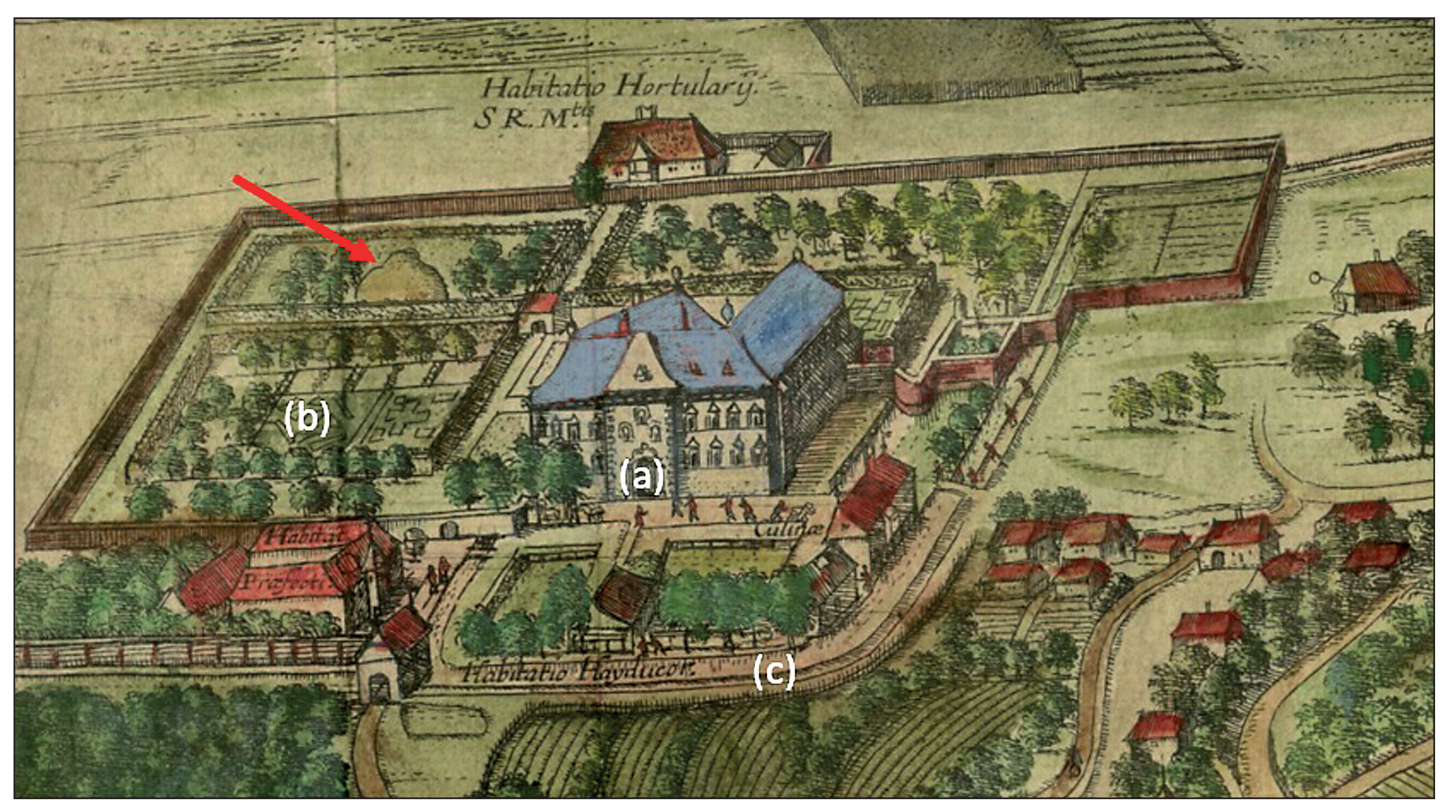

Fig. 1. The fragment of the Kraków panorama of 1603-1605 with the Esterka mound, based on [19] („Cracovia Metropolis Regni Poloniae in Civitates Orbis Terrarum”); ( $\mathrm{a}$ - palace, $\mathrm{b}$ - garden, $\mathrm{c}$ - the mill race canal of Młynówka Królewska) Rys. 1. Fragment panoramy Krakowa z lat 1603-1605 z kopcem Esterki, na podstawie [19] („Cracovia Metropolis Regni Poloniae w Civitates Orbis Terrarum”); (a - pałac, b - ogród, c - kanał Młynówki Królewskiej) 

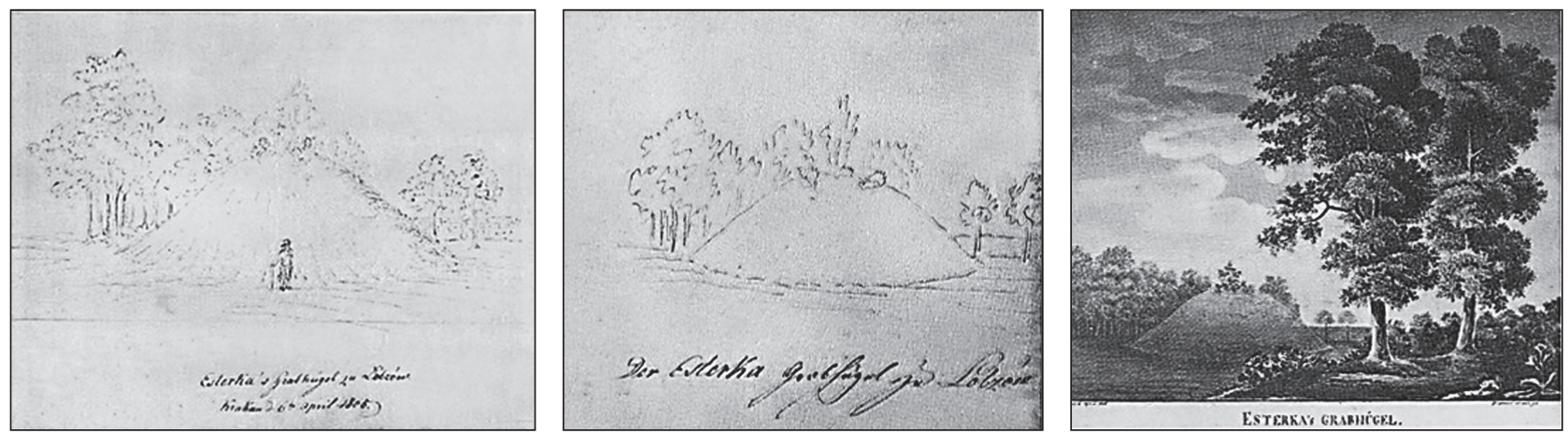

Fig. 2. The appearance of the Esterka Mound in 1805 according to Philip Usener [21]

Rys. 2. Wygląd kopca Esterki w 1805 r. według Philipa Usenera [21]

In the left part of the drawing, the area of the village Łobzów near Kraków was shown, with the palace, garden and the mill race canal Młynówka Królewska. The magnification of this fragment shows the mound, situated in the middle of the north-west quarter of the garden (fig. 1, the mound was marked by the red arrow).

This image of the Esterka Mound is its oldest image. The mound was not marked in the largest panorama of Kraków made by Matthäus Merian in 1619, despite the fact that the author was inspired by the earlier panorama, showing the mound. Merian, apart from this topographic feature, avoided presenting other details. Such simplification was to make the picture more artistic and nicer to watch [20].

The following three drawings presenting the Łobzów Mound come from the beginning of $19^{\text {th }}$ century. They were made in 1805 by Philip Usener during his short stay in Kraków [21]. They present the mound and its closest vicinity. The album of drawings: „Ansichten von Krakau und der gegend. MDCCCV. Ansichten aus Pohlen" is in the National Museum (Muzeum Narodowe) in Kielce (inventory number MNKi/GR/473). In one of the drawings of the Esterka Mound there is a human silhouette standing at the foothill of the mound. Thus its height can be estimated as 5-7 m. Usener's drawings have to be recognized as the most faithful images of the Esterka Mound from the beginning of $19^{\text {th }}$ century. There are no traces of digging through the mound in these pictures. It was dug through in 1787 [22].

The following two drawings of the mound come from magazines. The first was put on the cover page of „Przyjaciel Ludu” no. 18 of $31^{\text {st }}$ October 1840 [23]. It shows the mound seen through the hole in the damaged wall surrounding the garden (fig. 3a).
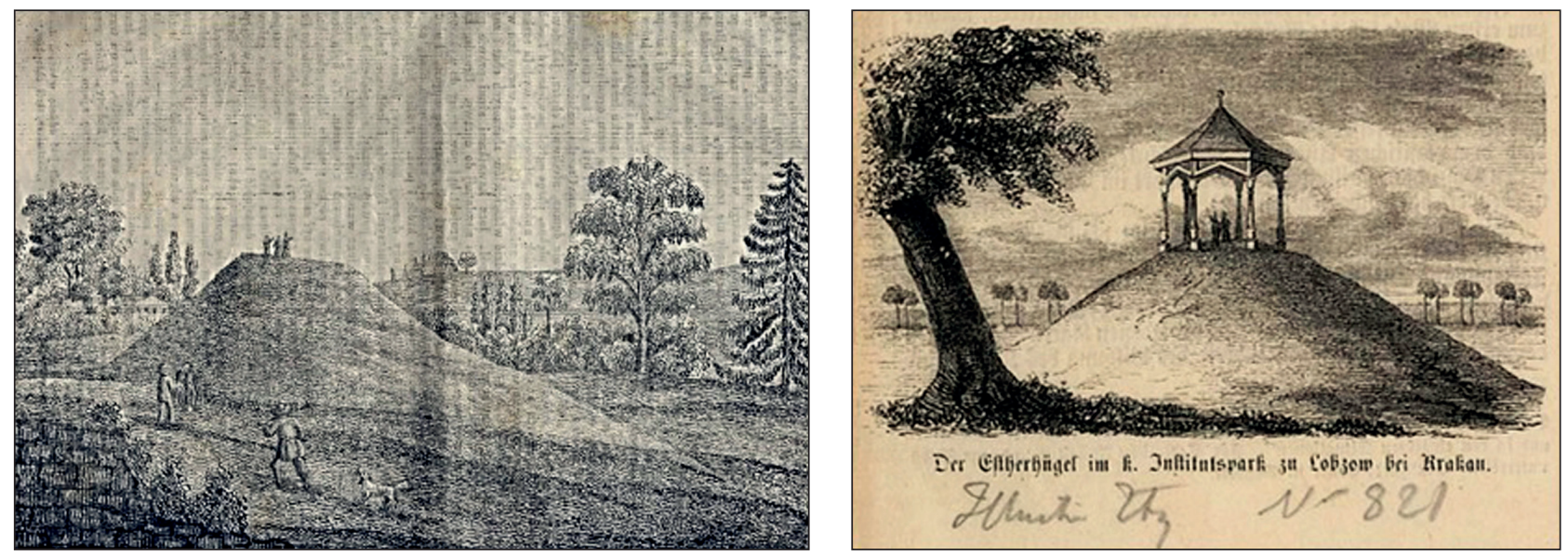

Fig. 3. Illustrations of the Esterka Mound in magazines; a) „Przyjaciel Ludu” of 1840 [23]; b) “Illustrirte Zeitung” of 1859 [24] Rys. 3. Ilustracje przedstawiające kopiec Esterki w czasopismach; a) „Przyjaciel Ludu” z 1840 r. [23]; b) „Illustrirte Zeitung” z 1859 r. [24] 
That drawing was an illustration for the published in the magazine fragment of the letter of 1827, describing the author's impressions from the trip to Łobzów. Similar illustrative character has the second drawing, published in 1859 (fig. 3b). Probably neither of these drawings was made from the nature. The mound in the drawings is much higher than the one depicted by Usener. The second picture is sometimes wrongly attributed to P. Usener [25]. The information obtained in the Section of Drawings in the National Museum in Kielce shows that the Usener's album contains only three drawings shown in fig. 2.

The following picture of the mound was presented in several photographs taken in 1927 , during the oath ceremony at the Reserve Officers School of Infantry (Szkoła Podchorążych Rezerwy Piechoty). The school was in Łobzów in the palace that had been converted by the Austrians in the half of $19^{\text {th }}$ century. A short note about the oath ceremony is in the magazine "Ilustrowany Kurier Codzienny" [26]. More photos of this ceremony where the Esterka Mound is seen are in the National Digital Archive (Narodowe Archiwum Cyfrowe) [27]. Fig. 4 presents three photographs where the mound is seen. It was in the northern part of the old garden, converted into military exercise area. Photograph $4 \mathrm{~d}$ was taken nowadays from a similar place as photograph 4c. In the background of both photographs there is a still existing building at the 14 Bartosz Głowacki street. This

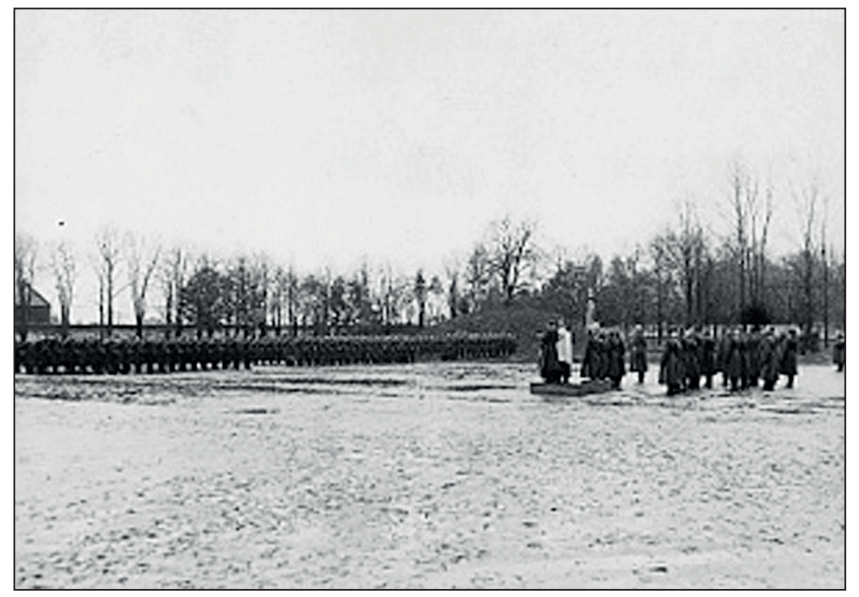

a)

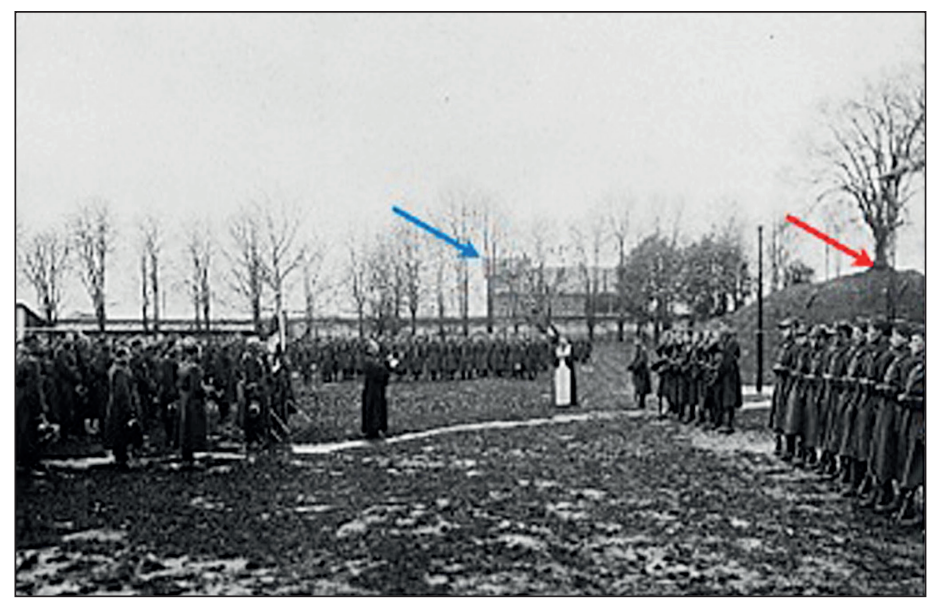

c)

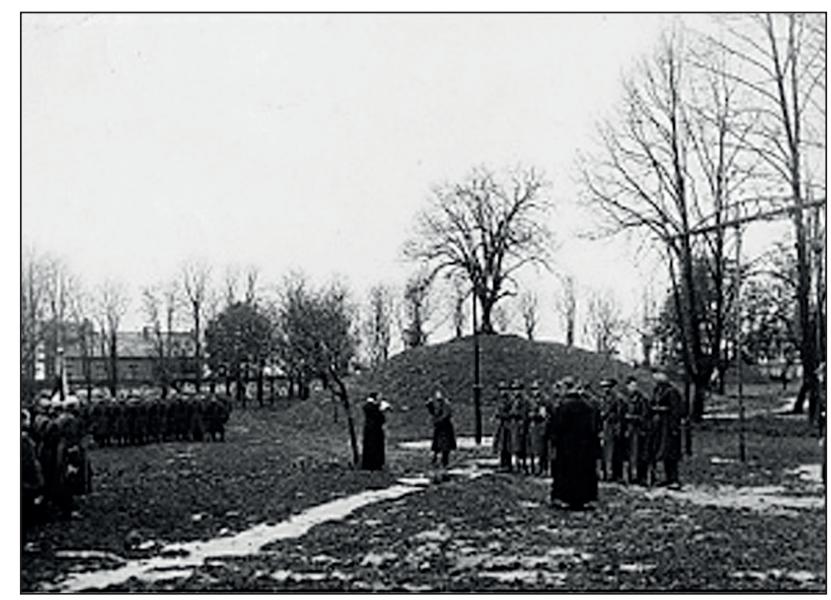

b)

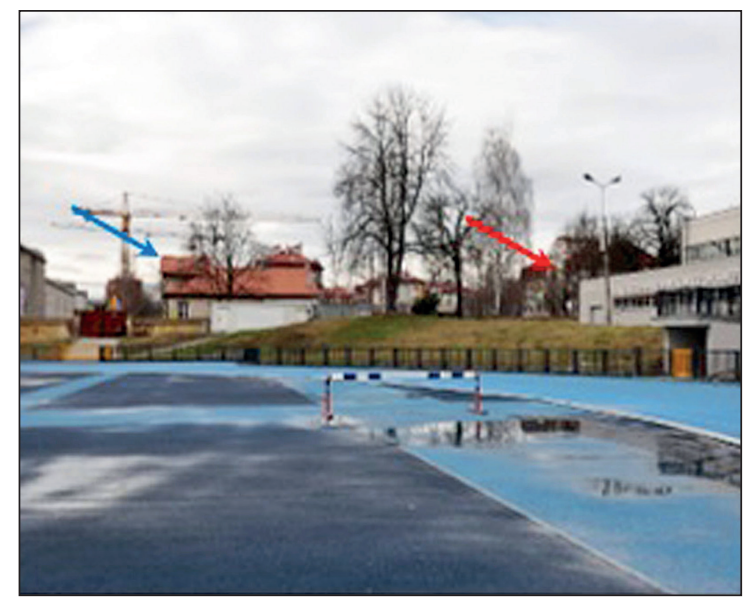

d)

Fig. 4 The fragment of the area of the former garden at the Łobzów palace; a), b), c) the area with the Esterka Mound, based on [33]; d) contemporary photograph of the area, corresponding photograph 4c (photo: P. Banasik)

Rys. 4. Fragment obszaru dawnego ogrodu przy pałacu w Łobzowie; a), b), c) teren z widocznym kopcem Esterki, na podstawie [33]; d) współczesna fotografia terenu, odpowiadająca fotografii 4c (fot. P. Banasik) 
building was a reference point to find the situation of the mound from such perspective. Blue arrows show the corner of the building and red arrows show the real peak of the mound and the corresponding point in the contemporary photograph.

The presented in fig. 4 old photographs of the mound are last real images of the Esterka Mound. It cannot be excluded that in the archives there are unknown aerial photographs of Łobzów from the period of the Second World War [28]. The Esterka Mound was liquidated probably shortly after the war [14]. The area of the former palace garden was converted into the stadium of the army sports club „Wawel”.

The supplementation of the iconography of the Esterka Mound are reconstructions of the appearance of the palace and garden from various periods of its existence. Many such reconstructions in the form of terrain sketches of $14^{\text {th }}-19^{\text {th }}$ can be found in [14]. Figure 5 shows another, more artistic reconstruction showing what the Łobzów palace and garden looked like in $16^{\text {th }}$ century [29]. In the foreground of the drawing there is one of the quarters of the garden, with the Esterka mound in the centre.

\section{ESTERKA MOUND IN THE TERRAIN SKETCHES AND MAPS OF KRAKÓW}

The Esterka Mound is a relatively small object. Thus in the oldest small-scale maps made at the beginning of $18^{\text {th }}$ century it was not marked. On the other hand, city maps (terrain sketches), although full of details, did not include Łobzów, situated several kilometres outside Kraków. The exception is the Kołłątaj's Map (Plan Kołłątajowski) of 1785 made in scale 1:3000 [30]. It covered Kraków and its suburbs with Łobzów. The Esterka Mound was marked with hatching, which was the way to mark hills in those times (fig. 6a). This is the oldest known marking of this mound in the map. The map was magnetically orientated southwards. The mound in Łobzów is in the right-hand side of the map.

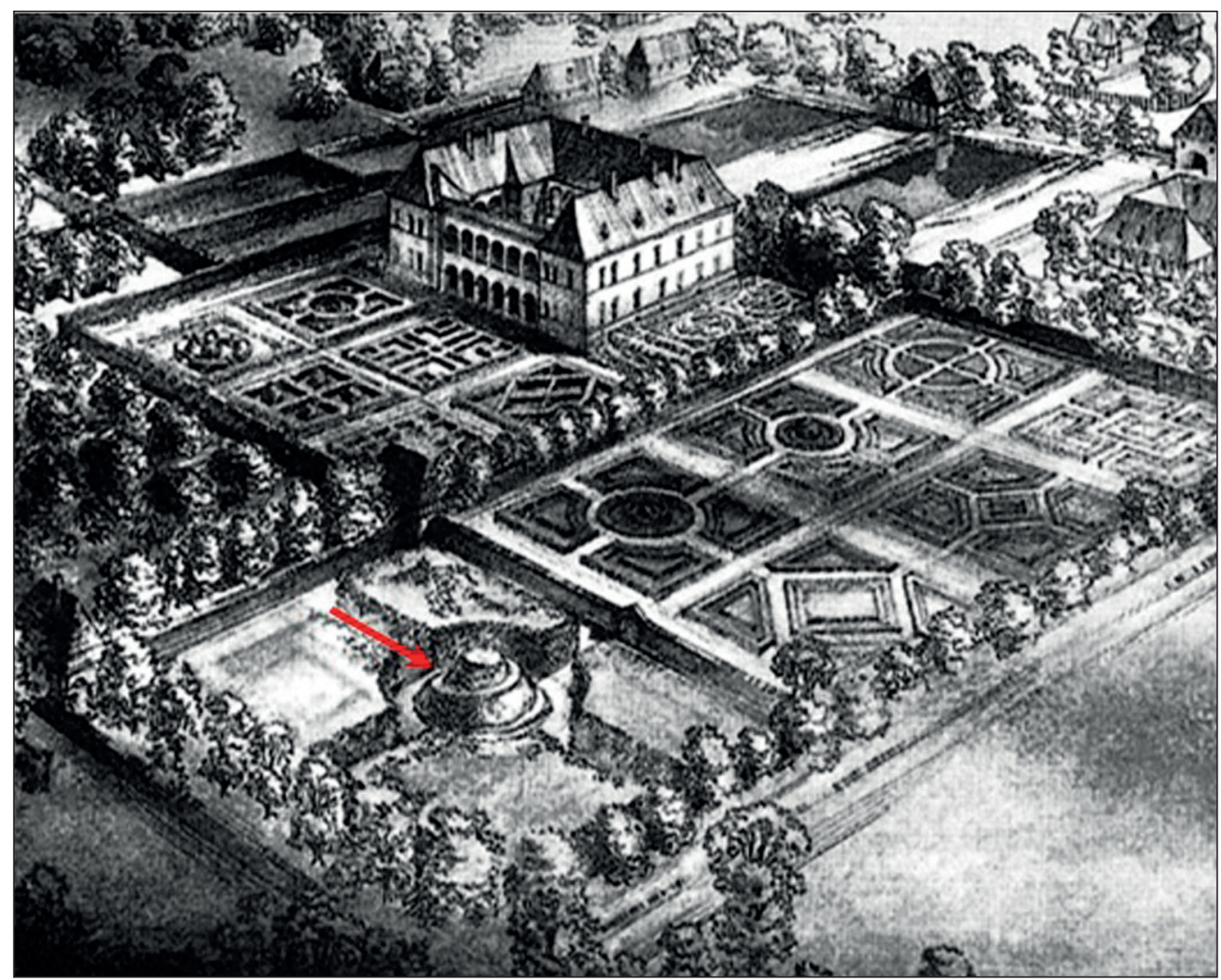

Fig. 5. The fragment of the reconstruction of the palace and garden in Łobzów of $16^{\text {th }}$ century, based on [29] Rys. 5. Fragment rekonstrukcji pałacu i ogrodu w Łobzowie z XVI wieku, na podstawie [29] 


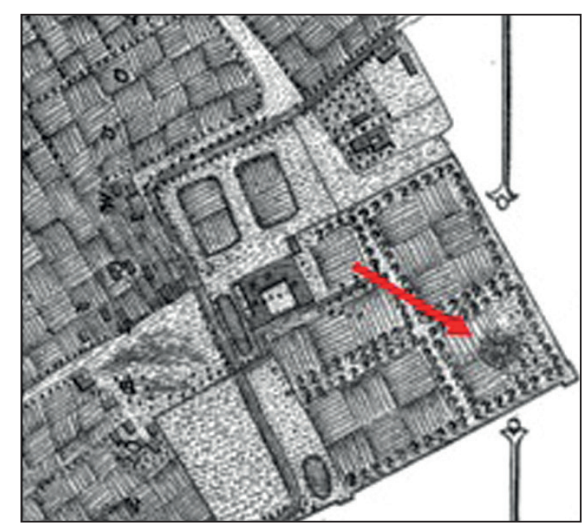

a)

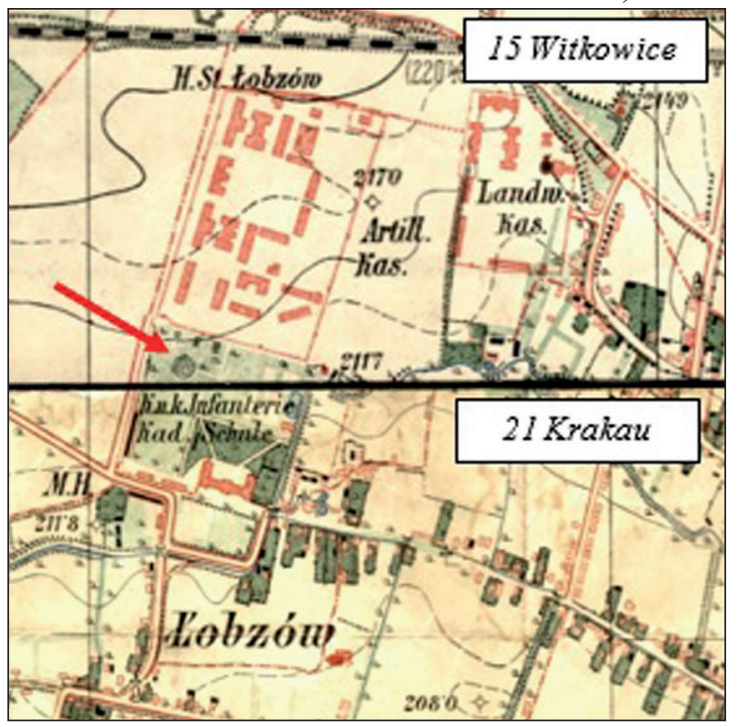

c)

b)
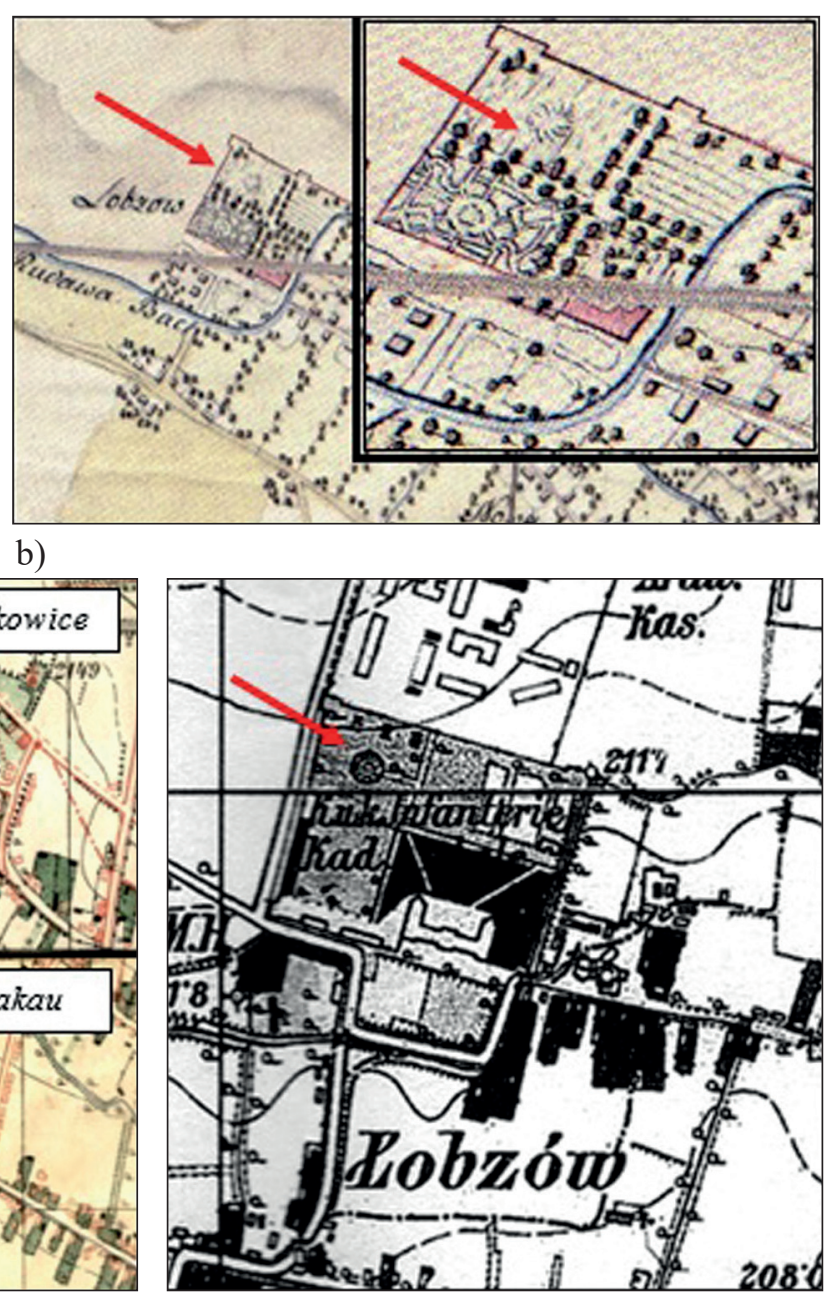

d)

Fig. 6. The Esterka Mound in the terrain sketches and maps of $18^{\text {th }}-20^{\text {th }}$ century; a) fragment of the Kołłątaj's Map of 1785 [30]; b) fragment of the Prussian Map of 1794 [31], c) fragment of „Special Ubersichts Plan von Krakau” of 1881-1904 [31]; d) fragment of „Festungs Umgebungsplan von Krakau” of 1904 [32]

Rys. 6. Kopiec Esterki na planach i mapach z XVIII-XX wieku; a) fragment Planu Kołłątajowskiego z 1785 r. [30]; b) fragment Planu Pruskiego z 1794 r. [31], c) fragment „Special Ubersichts Plan von Krakau” z 1881-1904 [31]; d) fragment „Festungs Umgebungsplan von Krakau” z 1904 r. [32]

The Kołłątaj's map was the oldest detail cartometric work, showing the royal mansion in Łobzów with the Esterka mound.

Another map, where the mound was marked is the Prussian Map (Plan Pruski) of 1794 [31]. This map has less cartometric details than Kołłątaj’s Plan. This is mainly due to its form (folded sheets) and small scale (1:12600). Fig. 6b shows the fragment of the Prussian Map with the area around the palace in Łobzów. Additionally, in magnification the application for the mound was shown.
The Esterka Mound was also put in two military maps made on the turn of $19^{\text {th }}$ and $20^{\text {th }}$ century, for the needs of the Stronghold of Kraków (fig. $6 \mathrm{c}$ and d). These are: „Special Ubersichts Plan von Krakau”, scale 1:10000 [30], and „Festungs Umgebungsplan von Krakau", scale 1:5000 [28]. The first map was made in 1881-1904 based on surveying in 1881-1884 [31]. The area of the Łobzów garden is on sheets „15 Witkowice” and „21 Krakau” (fig. 6c). Both military maps present similar state of the topography of Łobzów. One should assume that they were based on the same surveying ma- 
terials. The advantage of the second map is its greater scale and localization of Łobzów on one sheet.

Two latest maps showing the mound in Łobzów come from the half of $19^{\text {th }}$ century (fig. 7). The first of them is a detail cadastral map in scale 1:2880 (fig. 7a) [33]. This map was made in one of the cadastral systems $\mathrm{XY}$, made in the area of western Galicia [34]. Individual sheets of the map had cartographic control line (inch bars in the frame of the map). Due to them it was possible to calculate $\mathrm{X}, \mathrm{Y}$ coordinates of any points of the map in the cadastral system. Basic content of this map was the course of the borders of the real estate (parcels and buildings). This map comes from the period of the reconstruction of the palace and garden, made because of converting the area into military barracks [14]. In fig. 7a the original outline of the palace building (black line) was shown. The red line marks the building after the reconstruction. Additional content of the cadastral map includes selected elements of topography. The Esterka Mound is beyond them (fig. 7a).

Drawing $7 b$ presents the fragment of the map: „Mappa Łobzowa z przyległościami" (The Łobzów Map with the Adjacent Area) [35]. This map is also known as „Plan Gołuchowski” (Gołuchowski Map) [31], [36].
The map does not have any scale. Its georeference and exact time when it was made remain unknown. The marked buildings mainly correspond the ones presented in the cadastral map (fig. 7a). Thus it can be assumed that this map, like a cadastral map, was made in the half of $19^{\text {th }}$ century. Compared to the cadastral map, this map shows the management of the garden at the palace. The Esterka Mound is in the north-west quarter of the garden (fig. 7b). While analyzing this map it was noticed that the Esterka Mound, with the oldest part of the palace (eastern tower of the medieval castle) lie in the direction to the Wawel castle (fig. 7b) [36]. This can indicate that the mound was the element of the garden arrangement that had been carried out at the palace in Łobzów in $16^{\text {th }}$ century.

Large-scale maps presented in figures $6 \mathrm{a}, 6 \mathrm{~d}$ and $7 \mathrm{a}$ were used to locate the Esterka Mound precisely [37]. Coordinates $\mathrm{X}, \mathrm{Y}$ of the mound in the cadastral system were calculated based on the situation of other terrain points placed in the mentioned sketches and maps. Then the coordinates were calculated from the cadastral system into the accepted state system PL-1992 (X,Y) and PL-ETRF89 $\left(\varphi=50^{\circ} 04^{\prime} 38.5, \lambda=1954^{\prime} 28.9^{\prime \prime}\right)$ [38]. The accuracy of these coordinates was estimated $2 \mathrm{~m}$. The
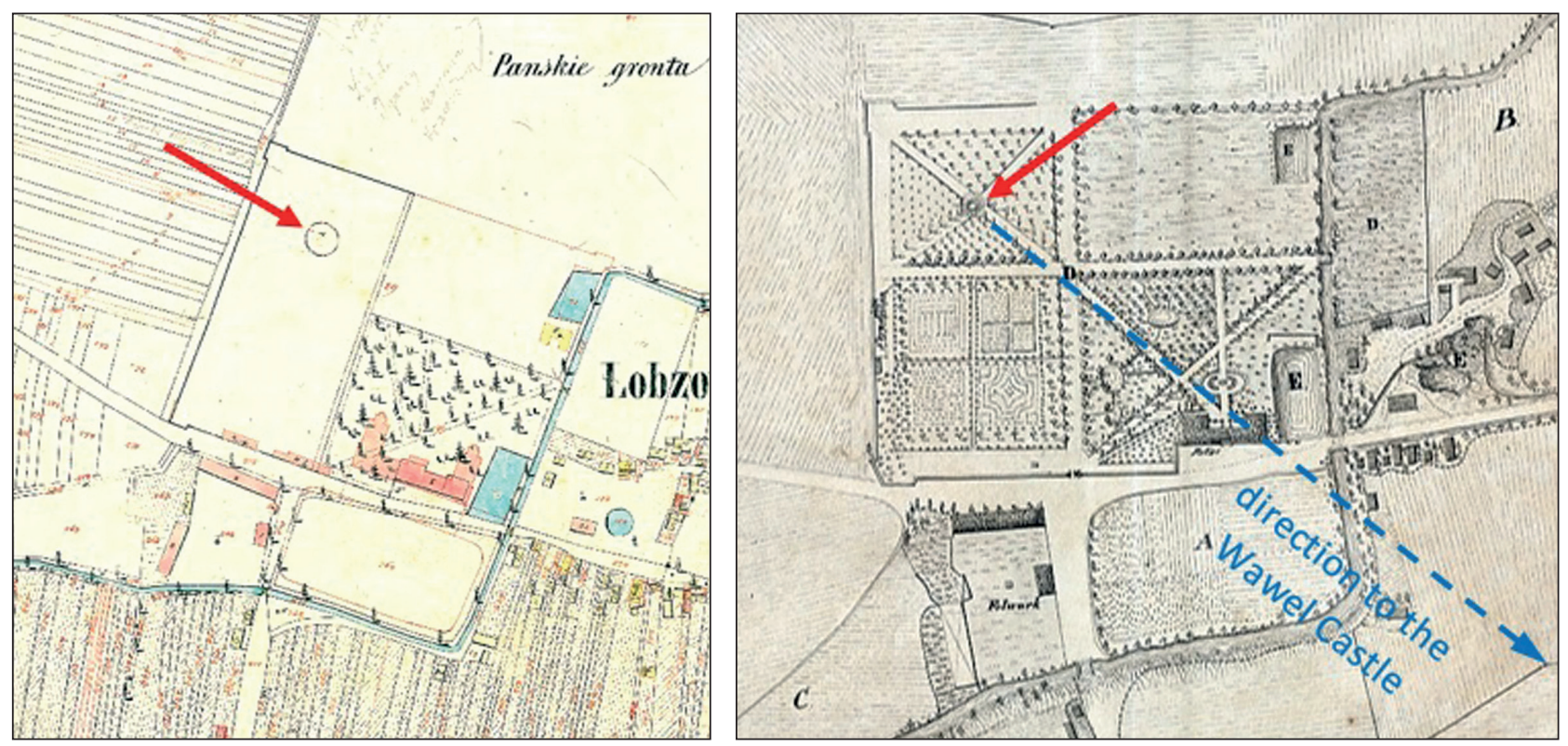

Fig. 7. The Esterka Mound in the cadastral map and the Gołuchowski Map; a) fragment of the cadastral map of 1848 - section WC XXXIX 12 dg Łobzów in scale 1:2880 [33]; b) fragment of „The Goluchowski Map” of the period 1824-1852 in scale of about 1:2900 [35]

Rys. 7. Kopiec Esterki na mapie katastralnej i Planie Gołuchowskiego; a) fragment mapy katastralnej z 1848 r. - sekcja WC XXXIX 12 dg Łobzów w skali 1:2880 [33]; b) fragment „Planu Gołuchowskiego” z lat 1824-1852 w skali około 1:2900 [35] 
coordinates of the Esterka Mound can be used to recreate this object, or supplementing educational trails and tourist routes with additional elements of the historic landscape of Kraków.

\section{SUMMARY}

The Esterka Mound in Łobzów is an example of an object of architecture that has been constructed since very early times. This mound most probably had the function of a scenery view mound in a garden at the royal mansion. It functioned in the cultural landscape of Kraków for at least 350 years. It was probably constructed at the end of $16^{\text {th }}$ century during making the garden at the Łobzów palace. There are also arguments in favour of the statement that the mound existed before the medieval castle was built. The legend connects this mound with a Jewish woman Esterka, as it was described in the Chronicle by Jan Długosz of $15^{\text {th }}$ century and later in the chronicle by Marcin Bielski. The character of Esterka can be also found in literature and painting ${ }^{1}$. One of the oldest iconographic documents shows the Esterka Mound in the panorama of Kraków from the beginning of $17^{\text {th }}$ century. The last iconographic document with the mound, are photographs from the inter-war period. Three hand-made drawings of the mound from the beginning of $19^{\text {th }}$ century are very reliable. Altogether the mound is seen in at least 9 iconographic documents.

More precise situation of the Esterka Mound can be found in 6 sketches and maps of Kraków and Łobzów. Attention should be paid to the oldest map Plan Kołłątajowski from the end of $18^{\text {th }}$ century and cadastral map from the half of $19^{\text {th }}$ century. Due to the very large scale of these maps, they can be used in a precise reconstruction of the mound's situation. On the other hand, „Plan Gołuchowskiego", the last map with the Esterka Mound contains valuable information referring to the garden at the palace. It follows that the mound had an important function among other objects of the garden arrangement.

The mound, although liquidated more than 70 years ago, is still the object of scientific interest. This is con-

1 Exmples: „Legenda o Esterce w literaturze jidysz i polskiej" [The legend of Esterka in Yidish and Polish literature] by Chone Shmeruk, and paintings by Władysław Łuszczkiewicz, Aleksander Lesser and Franciszek Żmurka, depicting the figure of Esterka the Jew. nected with the surroundings where a medieval castle and then a royal mansion with a garden were situated. The devastation of this historic area took place in the half of $19^{\text {th }}$ century and then just after $2^{\text {nd }}$ World War. For several decades the work to bring back the old appearance of this part of Kraków has been carried out.

The scale of this project can be seen in numerous plans of revitalization. This paper is a part of these activities. It contains systematic set of graphical pieces of information on one of the topographic elements of $Ł o b-$ zów, such as the Esterka Mound that used to be there.

This paper was made at AGH-UST within statutory research 16.16.150.545.

\section{REFERENCES}

[1] Buko A., 2006: Archeologia Polski wczesnośredniowiecznej, Wydawnictwo TRIO, Warszawa.

[2] Krassowski W., 1990: Dzieje budownictwa i architektury na ziemiach Polski, T.2, Arkady.

[3] Góral W., 2006: Aspekty geoinformatyczne i astronomiczne prehistorycznych kopców krakowskich i kopca Kraka w Krakuszowicach. Geodezja, T. 12, z. 2/1, Wydawnictwo AGH, pp. 209-220.

[4] Góral W., 2018: Krakus and Wanda mounds and the division of a year into eight parts, Geoinformatica Polonica, vol. 18, pp. 109-122 (DOI 10.4467/21995923GP.18.010.9 640).

[5] Banasik P., Góral W., 2016: Kopiec Krakusa a zachód Słońca w dniu przesilenia letniego - aspekty astronomiczno-archeologiczne, Materiały Archeologiczne XLI, pp. 301-312 .

[6] Gill G., 2002: Kopce w krajobrazie kulturowym Polski, Wydawnictwo DjaF , Kraków.

[7] Gawałkiewicz R., 2019: Mounds and barrows as important elements of cultural landscape of Poland, Geoinformatica Polonica, T.18, pp. 87-99.

[8] Florek M., 2008: Zagadnienie istnienia i funkcji tzw. wielkich kurhanów w Małopolsce w starszych fazach wczesnego średniowiecza, artykuł z Analecta Archaeologica Ressoviensia Tom 3, Rzeszów.

[9] Radzicka J., 2005: Krakowskie pamiątki związane z papieżem Janem Pawłem II, FIDES - Biuletyn Bibliotek Kościelnych nr 1-2 (20-21)/2005, pp. 159-178.

[10] Lempart M., 2008: Zapomniane dziedzictwo Nowej Huty Łuczanowice, Muzeum Historyczne Miasta Krakowa, Kraków.

[11] Tomkowicz S., 1908: Wawel. Atlas planów, widoków i zdjęć architektonicznych z XVII, XVIII i XIX wieku, Kraków. (https://jbc.bj.uj.edu.pl/dlibra/publication/211501/edi-

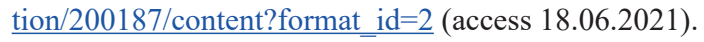


[12] Radwański K., 2003: Wielkie kopce krakowskie i próba uściślenia ich chronologii, Rocznik Krakowski T. 69.

[13] Rączka J.W., 1984: Królewska rezydencja pałacowo-ogrodowa na Łobzowie. Stan badań i zachowane źródła archiwalne (1655-1980), Teka Komisji Urbanistyki i Architektury, T. 18 , pp. 47-58.

[14] Bogdanowski J., 2001: Królewski ogród na Łobzowie. Wydawnictwo Vademecum. Kraków.

[15] (https://budzet.krakow.pl/projekty/1940-kopiec_esterki_z powrotem w parku krolewskim w lobzowie.html) (access 18.06.2021).

[16] Fischinger A., 1969: Santi Gucci, architekt i rzeźbiarz królewski XVI wieku. Seria Biblioteka Wawelska nr 3, Państwowe Zbiory Sztuki na Wawelu.

[17] Krasnowolski B., Rączka J.W., 2007: Królewska rezydencja w Łobzowie, [w:] Pałace i wille podmiejskie Krakowa, Towarzystwo Miłośników Historii i Zabytków Krakowa.

[18] Banach J., 1983: Dawne widoki Krakowa. Wydawnictwo Literackie, Kraków.

[19] (https://polona.pl/item/cracovia-metropolis-regni-poloniae,Mzk2NTc4OTM/0/\#info:metadata (access 18.06.2021).

[20] Komorowski W., 2019: Views of Cracow from the Old Polish Times in the Research of the History of the City: Picture, Sign, Symbol, Text. Zapiski Historyczne, National Museum in Krakow, T. LXXXIV, z. 1, pp. 135-167 (http:// dx.doi.org/10.15762/ZH.2019.46).

[21] Pieniążek-Samek M., 1995: Widoki Krakowa w albumie Friedricha Philippa Usenera, Rocznik Krakowski, T. 61, Towarzystwo Miłośników Historii i Zabytków Krakowa, pp. 27-58.

[22] Grabowski A., 1905: Kraków ijego okolice. Nakładem Księgarni Friedleina, Kraków.

[23] Przyjaciel Ludu, nr 18, rok 7, 31.10.1840. (https://jbc.bj.uj. edu.pl/dlibra/publication/645161/edition/612217) (access 18.06.2021).
[24] (http://ct.mhk.pl/wps/portal/mhmk/main/strona-artefaktu/?artefactId $=\{$ EC01CC23-FCDF-4E67-9E5D-B73716E 9EA85\}) (access 18.06.2021).

[25] (https://en.wikipedia.org/wiki/Esterka) (access 18.06.2021).

[26] Ilustrowany Kurier Codzienny, 23.10.1927, pp. 16. (http:// mbc.malopolska.pl/publication/33326) (access 18.06.2021).

[27] (https://audiovis.nac.gov.pl/obraz/61918/b0175eccb9a663daee8b994c27684b35/) (access 18.06.2021).

[28] (https://ncap.org.uk/) (access 18.06.2021).

[29] Majdecki L.2007: Historia ogrodów, t. 1, PWN, Warszawa.

[30] Odlanicki-Poczobutt M., Traczewska-Białek Z., 1990: Plan Kołłątajowski miasta Krakowa z 1785 r., Geodezja 110, Wydawnictwo AGH, Kraków.

[31] Katalog dawnych map polskich XVI-XIX w., PWN Warszawa-Kraków, 1981.

[32] Janczykowski J., 2000: Atlas twierdzy Kraków, Seria 1, T. 12, Mapa Twierdzy (1899-1904), (arkusz 15 i 21), Urząd Miasta Krakowa, Oddział Ochrony Zabytków, Kraków.

[33] (https://szukajwarchiwach.pl/29/280/0/9.1/1228/ str/1/1/15/Pbz5-cHU5JC5H0rQrJHRig/\#tabSkany) (access 18.06.2021).

[34] Fedorkowski W., 1974: Ewidencja gruntów, PPWK, Warszawa.

[35] (http://ct.mhk.pl/wps/portal/mhmk/main/strona-artefak$\underline{\mathrm{tu} / \text { ? artefactId }=\{8 \mathrm{BD} 06 \mathrm{E} 58-5091-429 \mathrm{E}-8 \mathrm{E} 1 \mathrm{~A}-54184}$ 3F66472\}) (access 18.06.2021).

[36] Rączka J.W., 1984: Królewska rezydencja pałacowo-ogrodowa na Łobzowie. Stan badań i zachowane źródła archiwalne (1655-1980), Teka Komisji Urbanistyki i Architektury, T. 18, pp. 47-58.

[37] Banasik P., 2009: Wyznaczenie położenia kopca Esterki na podstawie dawnych map z obszaru Krakowa, Geodeta 10/2009, Warszawa.

[38] Rozporządzenie Rady Ministrów z dnia 15 października 2012 r. w sprawie państwowego systemu odniesień przestrzennych, Dz. U. 20102, poz. 1247. 